\title{
TAKING HOLD OF THE FUTURE: ACTIVE CHILDBIRTH PRACTICES AND BELIEFS IN ROMANIA (IN THE HOME COUNTRY AND IN MIGRATION)
}

\author{
Adina Hulubaş \\ Senior Research Fellow, PhD, Department of Ethnology \\ "A. Philippide" Institute of Romanian Philology \\ Romanian Academy, Iaşi Branch, Romania \\ adina.hulubas@gmail.com
}

\begin{abstract}
The relatively recent urbanization process in Romania allowed traditional knowledge to be transmitted, despite industrialization and technology diffusion. Childbirth is still a mysterious event, and magic thinking fills in the gaps of science in order to keep parents confident and at peace. Taboos are obeyed after birth and before christening, only to reach the phase when the future can be moulded: specific elements are chosen for the ritual bath, the child has to touch several objects that would make them smart, a good singer, etc. A year later, their future occupation will be predicted in a specific ceremony. All these active practices are found in urbanites' families, and also in Romanian immigrant communities in Western Europe. Rituals are mostly compared to neighbouring countries, but also to other distant cultures that show striking similarities. This large geographical spread indicates Indo-European synergies. The identical form of the post-liminal practice of haircutting in Eastern Europe and the Asian rite of passage have not been previously dwelt upon, and it implies the existence of traditional thinking universalia.
\end{abstract}

Keywords: birth customs, magic thinking, migration, rites, superstitions

\section{INTRODUCTION}

Being with child still tests the human ability to master tranquillity in the face of unpredictable outcomes. The traditional worldview helps the future parents considerably. Societies that have recently experienced urbanization (like Romania, where intense internal migration started in the 1960s due to forced industrialization) managed to maintain active magic practices despite the loss of traditional context. It is typical not only for childbirth, but for other situations, too. One can easily observe elements that speak about a former 
rural education in cities. Daily superstitions, such as to avoid hugging someone on the threshold or take the garbage out only when there is sunlight, are rather common. The taboos are often obeyed without the need to understand their significance, the fact that they were transmitted by the elders being more than enough for urbanites. The doorway has been perceived as a sacred space in many ancient cultures of the world, and the resident deities should not be offended by people. Contact with this place in the house is only permitted in ceremonial contexts. As for the trash that should not be disposed of at night time, it represents the well-being of the family, its wealth, and all will be lost in the dark, never to return again.

Recent interviews with 31 Romanian immigrants from Italy and Spain, recorded as part of a project $^{1}$ on their acknowledged identity after arriving in their respective host countries, revealed that traditional gestures are performed abroad, too (some individuals even risk being fined, but they continue to take the garbage out before sunset). Even more so, the rites of passage, such as giving birth or getting married, are more strictly followed in the attempt to assert one's cultural identity.

Traditional codes for life events prove themselves persistent in Slavic regions, too:

The political, social, cultural, and daily life of an ordinary urban Ukrainian is explained by members of the community not through natural causes, but through traditional understanding of the way things happen: if your husband has left you, you must look for the white witch who will help you to win him back; if you are frequently sick, you must look for the black witch who is making you sick. People sincerely believe in superhuman (demonic) influences in their lives, and try to protect themselves with the help of traditional knowledge. (Golovakha-Hicks 2008: 43)

In the case of childbirth practices, folk knowledge managed to fight both against the challenge of uncertainty and against negative states of mind, which might affect pregnant and parturient women. Customs, taboos, and magic gestures that are still performed by Romanians are successful in creating a self-induced confidence in future events. E.G.V. has lived in Rome for the past 20 years and she stressed the fact that all rites pertaining to birth have been enacted "exactly as in Romania". Moreover, she explained why she followed through with customs in clear psychological terms: "It gives you a guarantee, and you are at peace that you did everything for your child to be well." The ontological process of having children reveals itself as "an intimate and complex transaction whose topic is psychological and whose language is cultural" (Jordan \& Davis-Floyd 1993 [1978]: 3). In the following sections I investigate such traditional codes used to pre-set the course of events for a new member of the community. 


\section{FIELDWORK AND THEORETICAL BASIS}

Ethnographic data comes from three different types of fieldwork: the most recent interviews (with a semi-directive approach based on a 35-question questionnaire) were recorded between 2017 and 2019 in Rome, Italy, and Iaşi, Romania. Romanian immigrants who stayed in their destination countries for periods ranging between 7 and 28 years shared their life stories and reckoned the importance of cultural heritage in the effort of adaptation. Previously, three interviews were held in Romania with emigrants to Italy, Spain, and Greece, the latter having decided to remain in her home country for good. The second type of data is also recorded in urban settlements. A post-doctoral project (implemented from 2011 to 2013) allowed me to investigate socio-cultural patterns that characterize migrants and their reaction to the surrounding world when it comes to childbirth customs. The respondents were 23 urbanites, and their responses were compared with information gathered from their friends and family who never left the villages.

The dynamics of customs and beliefs could not be understood properly without a clear image of their initial rural form. The Folklore Archive of Moldavia and Bucovina, founded in 1970, provided the analysis with a rich amount of data on childbirth that I classified and discussed in a book (Hulubaş 2012). All these milestones guided the conclusions on the role played by traditional knowledge in the present-day struggle, since I used the same questionnaire for rural and urban settlers and improved on it for the discussions with immigrants. The same districts that are covered by archived data were investigated for a post-doctoral project, and the majority of the immigrants came from these parts of Moldavia (a north-eastern region of Romania). While in 1970 recording was made on the tape-recorder tape, modern devices were used in 2011 and present-day interviews.

Scholars agree on the fact that the social birth of the child doubles the biological one (see, e.g., Laderman 1984: 549; Pop \& Ruxăndoiu 1978 [1976]: 189; Kabakova 2000: 90; Bartoli 2007: 236; Mathole \& Shamu 2009: 209; Crețu 2014: 85). The "experience is socially constructed" (Liamputtong 2009: 175) and much effort is put into achieving the best qualities for the individual to be easily accepted and even treasured by the community they are part of. "Integration rites and ceremonials" seem to dominate childbirth customs (Pop \& Ruxăndoiu 1978 [1976]: 183), but the coming into the world has in fact three clearly delimited phases. The first is obviously biological and it is defined in Arnold van Gennep's terms (1960 [1909]) by liminal rites. The second birth is spiritual and it consists in the Christian baptism where the entire body of the child aging around 40 days is submersed in water to symbolize the death of the heathen being and the appearance of a new, superior individual. The godmother 
and the godfather, whose selection is based on their moral qualities, assist in this becoming. Therefore, the social birth is the last to take place, also by the hands of the godmother who will mould the profile of the baby, as seen below, in the last section of the paper. Both the spiritual and social beginnings are part of post-liminal rites.

\section{THE WOMB OF TOMORROW: REGULATION OF THE PREGNANT WOMAN'S BEHAVIOUR}

Before any of this could happen, pregnancy has to be completed with a high level of consciousness on what is harmful and what is a good omen for the unborn child. The future mother is highly receptive to the world around her, and there are two types of influences that she needs to manage: the spontaneous, negative ones, cast by people and supernatural entities, and the intentioned positive actions performed by her or members of the community. While the first ones impose an apotropaic reaction, the second ones focus on symbols that augur well (Hulubaş 2014: 117).

As research showed, the former, negative category is still present in the minds of urbanites and immigrant mothers. Three women who experienced their pregnancy abroad declared that they avoided looking at ugly sights or disabled people for fear their child will turn up alike. One of them even used a specialized formula against this unwanted contagion: "Tu ca tini, copilu' meu ca mini!" (Be as you are, let my child be like me!). According to the records of the Folklore Archive of Moldavia and Bucovina, the precaution of staring at less fortunate people with an unpleasant appearance has been documented in all villages. However, this apotropaic saying has only been found in Tansa, in the same district that represents the native place of one of the interviewees. Iaşi is also the present settlement of S.T., an urbanite that indicated this precise formula as a way to ward off the danger of giving birth to a child that resembles the uncanny person that startled her. The conviction is common throughout the world. Lise Bartoli noted similar beliefs in Sri Lanka, Cameroon, Madagascar, and Turkey, where pregnant women constantly look away from ugly people and are in search of the beautiful ones (Bartoli 2007: 93).

Immediately after birth, the child may become an object of negative attention. The fear of being overlooked (Rom. deocheat) worries most of the new mothers from towns situated in and outside Romania. Tying a red thread around the baby's wrist is one of the common ways to divert the gazes of people around both in Romania and in Polesie, where a red woollen thread was tied to the child's right hand (Tolstaia 2009: 234). T.C. and C.T. trusted this strategy and 
used it for their children who were brought up in Rome. The urbanite mothers S.G. and M.G. declared that such an accessory is mandatory for the newborn, while C.T. from Italy explained this measure under the authoritative label of transmitted knowledge: "I do it because this is how it is done, that is the way tradition wants it". The motivation is similar to what urbanites in Romania answered to the questions on how they learned about customs and why they continue to observe them. Numerous phrases contained the word elders as a supreme argument for the necessity and efficiency of traditional practices (Hulubaş 2014: 53).

The fact that your grandparents taught you something is more than enough for the perpetuation of gestures and rites; it simply excludes any other quest on the meaning, and this reaction is mostly represented in a specific type of community: "the oral tradition of a folk society has no check or competitor" (Redfield 1947: 296). G.D. lived in Torino for 13 years and decided to return to Romania in 2013. When I asked her why she observed certain taboos she answered in the same manner rural inhabitants do, by stressing the infallible cultural system: "This is what I heard [that has to be done], I know it is good [to do it], if that is what she [her grandmother] taught me...". M.A., an urbanite from Focşani, ended her life story proving that superstitions are helpful with the following words: "What is learned from our elders... [is always true]".

The good looks of the unborn baby are also kept in mind when it comes to stealing various things. All rural and urban respondents were familiar with the superstition that the shape of an object stolen while being pregnant will appear as a birthmark on the child's body in the same place the mother touched herself after stealing. E.C. lives in Rome and she was fully aware of this interdiction when she brought her twins into this world. The same precaution was respected by M.N. in Spain. "The fundamental principle is that by creating some definite magic analogy the desired object or event is simultaneously assured in reality. Basically, the image and the reality consequent on it are magically identical" (Werner 1980 [1926]: 365). Some time ago in Moldavian villages future mothers would make use of the stealing taboo and take wood shavings from carpenters without permission, in order to have curly-haired babies. They placed them in their bosom to obtain contagious magic (Hulubaş 2012: 176).

Practices that augur well for the baby-to-come have not been found today in interviews carried out in Italy or with the emigrant who turned home for good from Greece. Archived documents indicate that a few decades ago pregnant women used to stare intentionally at beautiful people and to comb their hair on the threshold in order to magically gain the pleasant appearance of their children (Hulubaş 2012: 176). Therefore, the environment used to be carefully mapped for bad and good omens and people knew that on the one hand, "being 
pregnant means one's freedom of body and mind: every gesture, every word spoken, every movement of a pregnant woman also involves the child" (Gélis 1991: 66); on the other hand, unseen forces can be manipulated for the benefit of the mother and her child.

\section{IN THE HANDS OF GODPARENTS: BAPTISMAL RITUAL AND THE FIRST BATH}

Both the spiritual and social birth have to be mediated by people who have proved worthy of being godparents. Their moral profile and social position are essential for the well-being of the child, since it is believed that they will follow their steps. The relationship created by baptism is rather magic since urbanites, like rural inhabitants, are convinced that babies will grow to resemble their godparents. Hence, they have to be "well off, lucrative people, not just anybody", as P.T. declared. Romanian immigrants always choose people coming from their country of origin, a preference that is present in all the rites of passage performed abroad: the wedding sponsors and the recipients of alms have to be Romanians, since other nationalities "do not understand these things", as several immigrants declared.

Social organization around the event of childbirth as an institution has already been noted in relation to the role of empirical midwives by Mongeau, Smith and Maney (1961: 498). Moreover, the Romanian customs create a hierarchy that places godparents on top, since it is forbidden to ever upset them or to have an argument with them. Unlike in the English language, the relationship between the parents and the godparents is defined with a special word that means "with the mother". Cumătri comes from Latin com and mater, and has equivalents in other Romance languages: comare in Italian, comadre in Spanish, commère in French. So they are just as involved in raising the baby as biological parents, but before that they get to mould the child's future through Christian baptism and the following ritual bath. In Guatemala the traditional birth attendant is called comadrona, and 49 percent of labours were still assisted by them at the end of the past century (Callister 1998: 290). So, linguistically speaking, the godmother and the midwife share the same function, since both are "with the mother". Furthermore, in Romania the midwife used to baptize the newborn and became its godmother if the baby was weak at birth and there was a chance it might die.

The ATU classification of tales reflects the importance of choosing righteous spiritual parents under type number 332: Godfather Death. In these texts, man selects a sponsor who treats everyone alike - Death. Romanian variants grant 
a feminine gender to this character, proving once more that the woman bears a more complex ritual role: Moartea cumătră (Godmother Death). Such a tale recorded in Straja, Suceava, in 1977, is even more striking since the new father refuses God himself and also Saint Nicolaus, for they are not "fair men": they allow some people to be wealthy, others to be poor, some are made beautiful, others ugly, and so on. Death, on the contrary, comes to the young and the old, the rich and the poor in an equal manner, and therefore it is "a righteous person" (Hulubaş 2012: 378), suitable to baptize the newborn.

During the religious service the godmother has to hold the baby on her right arm, according to numerous statements archived in the database mentioned above. The same belief is encountered when it comes to the first time the baby is breastfed: it has to suckle from the right breast in order to be right-handed and to be treated right in life. The belief is common in all Slavic areas where explanations vary from avoiding the risk of becoming left-handed to warding off the possibility of growing into a person with evil eyes (Tolstaia 2009: 235).

This spatial choice was acknowledged by three of our urbanite respondents and it is part of an imagery that divides the surroundings into two opposite categories: right is associated with positive characteristics, whereas left refers to their opposite. While Slavic people share the same antagonism of the space visible in everyday life and in the rites of passage (Tolstaia 2009: 233), Mara Mabilia discussed such implications at a distant population, in Tanzania, proving that beliefs are built on a perceptive universalia: "the east, the south, above, men, the right hand, light, fertility and life; and on the other, the west, the north, below, women, the left hand, darkness, sterility and death" (Mabilia 2007 [2005]: 28).

From baptism to the ritual bath given to the baby on the next day, the godmother gets to write the baby's fate through her gestures. Both submersions are "rites of incorporation" (Gennep 1960 [1909]: 54), and social acceptance follows the religious service. Twenty-four hours after the Orthodox baptism, friends and family are expected to gather again to witness the godmother wash up the child. It is fairly important that she is thorough during this bath, because it is supposed to influence the level of cleanness in the child's life, the way they will smell and clean themselves. R.I. and M.T. indicated this in the interview recorded in Rome, saying that "the baby will be just as clean as their godmother makes them", and several urbanites told personal stories about improper washing. M.A.'s son was not bathed well, apparently, and he now suffers from a skin condition on his head. Magic thinking was transmitted to him as, according to his mother, he often says: "Oh, mother. My godmother... I'm going back to her to wash my hair again, not to have crusts on my scalp".

The attention paid to the neatness of clothing is also essential. Urbanite S.T. explained all the steps that echo back after some time: 
You have to wash them little by little, as they say... all over the body, you must not miss any spots on the child's body, you wash them with the corner of the baptism cloth and soap, and blow gently over them with basil. If she doesn't dress them properly, and this is another issue, there has to be no wrinkle in their clothes, all set up and unfolded ... Everything they wear shouldn't be wrinkled or tight on their body, they have to be dressed properly, because this is how they will dress when they grow up.

These clothes represent the second one out of the three gifts (consisting in an entire outfit for the baptized baby, in both cases) that the godparents have to make. The last one is given when the child turns one and a haircut has to be performed. The clothes seal the connection between them and the child (Văduva 1997: 97).

It is compulsory to put the water in the tub in just one pour. If it is too hot people wait for it to cool on its own, because adding cold water would result in misfortune: the child ends up having two marriages when they grow up. This belief is widely spread in villages in Moldavia (Hulubaş 2012: 201-202) and was also mentioned by two immigrants in Rome. Everything that comes in contact with the new baby is decisive for their future.

Initially scăldătoarea (the bath) was a women's gathering only, and the midwife was the one to prepare ritual ingredients. Today, men also attend this event, together with the godfather who holds the lit baptismal candle as long as the washing takes place. Hence, not only the baby becomes the beneficiary of symbolic gestures and objects, but also the group reinforces the bonds: "A ritual is not just a pattern of meaning; it is also a form of social interaction" (Geertz 1957: 52).

The bathtub also contains the cloth used during baptism (Rom. faşa) and a large number of ingredients intended to influence the future of the child on a magic level. They can be divided into four types of symbols: elements that bring good health, some others for beauty, objects improving the child's abilities placed under the tub, and wealth-implying ingredients.

The ritual was performed or witnessed by nineteen of the interviewees abroad. Nine of them stressed that the ritual bath was organized just the way it is done in Romania, and one even offered the word home (Rom. ca acasă) for this comparison. Rituals are not exposed to change or oblivion at the first generation of migrants, a conclusion that became obvious also during interviews with urbanites. And if we introduce the third element of comparison - the rural practice - into this picture, it is safe to say that little difference can be noticed between the choices made by immigrants for the ritual bath and the traditional content, even though no less than five decades have passed since the first recording of such events for the Folklore Archive of Moldavia and Bucovina. 
Basil is the most common ingredient for the second ceremony, and this is what documents from the Folklore Archive of Moldavia and Bucovina also indicate (Hulubaş 2012: 257). One respondent indicated the precise meaning of this ingredient - basil will bring good luck (Rom. noroc) throughout the child's life. The other respondents did not know the specific motivation. C.T. reacted in a slightly irritated manner to my insistence on learning the significance of each magic element she added to the bathing water: "I don't know what to tell you. I know it is good to have them put inside, but to tell you exactly what each and every one means..." Once again, knowledge of cultural heritage is enough; one does not need to know the purpose of the rituals, the feeling of safety induced by them suffices.

Health is magically attracted by adding a beaten egg to the water, along with milk. Both these products nourish the skin, so their immediate effect is visible. The egg will continue to function as a symbol during childhood so that the baby will be healthy / whole like an egg is. The birthday grab, organized when the baby turns one year old, presents the child with various objects, as is discussed in the following section, and egg is one of them. In villages the child takes the first steps by following a rolling egg on the floor. In fact, the egg is a prominent symbol during all rites of passage (Ciubotaru 2012: 108-120), given its mythology. Milk is associated also with feminine charms in Christmas carols (Brătulescu 1964: 167) as well as with good health and rebirth, the latter being a part of liminal rites such as the wedding day. In ATU 425A fairy tales, The Animal as Bridegroom, the bride is taking a bath in milk to prepare herself for the life that she is about to experience. Moreover, in some other fairy tales, horses transform themselves from runts to winged stallions by being bathed in milk (Teodorescu 1996: 43). Bread used to be added to the bathing water, too. I only found it mentioned by three urbanites from Iaşi, but it was common for the majority of villages in Moldavia (Hulubaş 2012: 251). Along with milk, home-made bread is often a ritual gift in childbirth customs (during the first visit to the newborn, it was given to the midwife for her services, colacii (kneaded bread) for the godparents, etc.) and all rites of passage. Immigrants, for example, confirmed that brides still go through a ritual that consists in having a special loaf of bread broken above their head by their confirmation sponsors. These food items "with a noteworthy positive symbolism reveal the accent placed on spiritual meanings of the gift, in the patterns of traditional life" (Văduva 1997: 71).

Beauty is the second aim that is magically pursued according to folk convictions. Flowers or petals, more exactly rose petals, have often been indicated both by immigrants and urbanites (Fig. 1). The child will bloom like the flowers and smell like them, too. But it is not enough to have beautiful features, one has to 
be attractive to gain social visibility, hence women add honey or sugar in the water. The baby will grow to be sweet, as many informants explained, meaning that everybody will be fond of him/her. The ingredients mentioned above and all the following ones used to be added in the first bath that cleansed the baby after expulsion. A ritual text gave the codes for symbols: the child will become "precious as silver / sweet as honey / good as bread / healthy as an egg / rosycheeked as a peony / attractive as basil / and white as milk" (Marian 1995: 58). Feathers are also used to obtain lightness of movement.

Another type of food - rice grains - is also put in the bath according to three immigrants. Its purpose is to acquire wealth, as urbanite M.D. explained: "Just as a rice grain expands a lot and it is useful, the child will thrive a lot and get help". More objects bringing good fortune in life are represented by money and gold.

Being oriented towards the future, the act performs the function of a wish; the magic objects used during these rites are selected in accordance with a comparisons system that connects them with fundamental aspects of the child's status, behaviour, and destiny. (Pop \& Ruxăndoiu 1978 [1976]: 184)

Future abilities were vivid in the mind of the midwife and they were suggested to the newborn right after birth. The baby was put lying on a book, notebooks, and pencils, or a tool was given in its little hand or a pencil, to allow him or her to be good at a certain job when they grow up (Hulubaş 2012: 197-198).

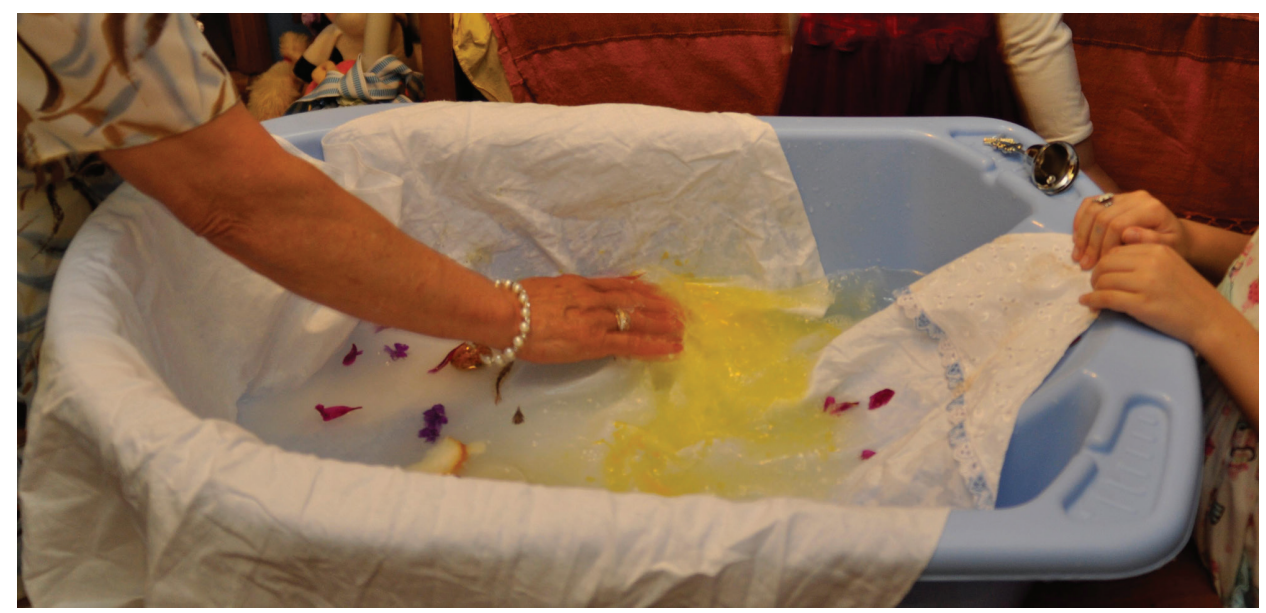

Figure 1. Preparation of a bath in Iaşi. The egg and petals are visible. A bell lies on the rim of the bathtub to positively influence the baby's voice. Photograph by Sergiu Ciubotariu 2013. 


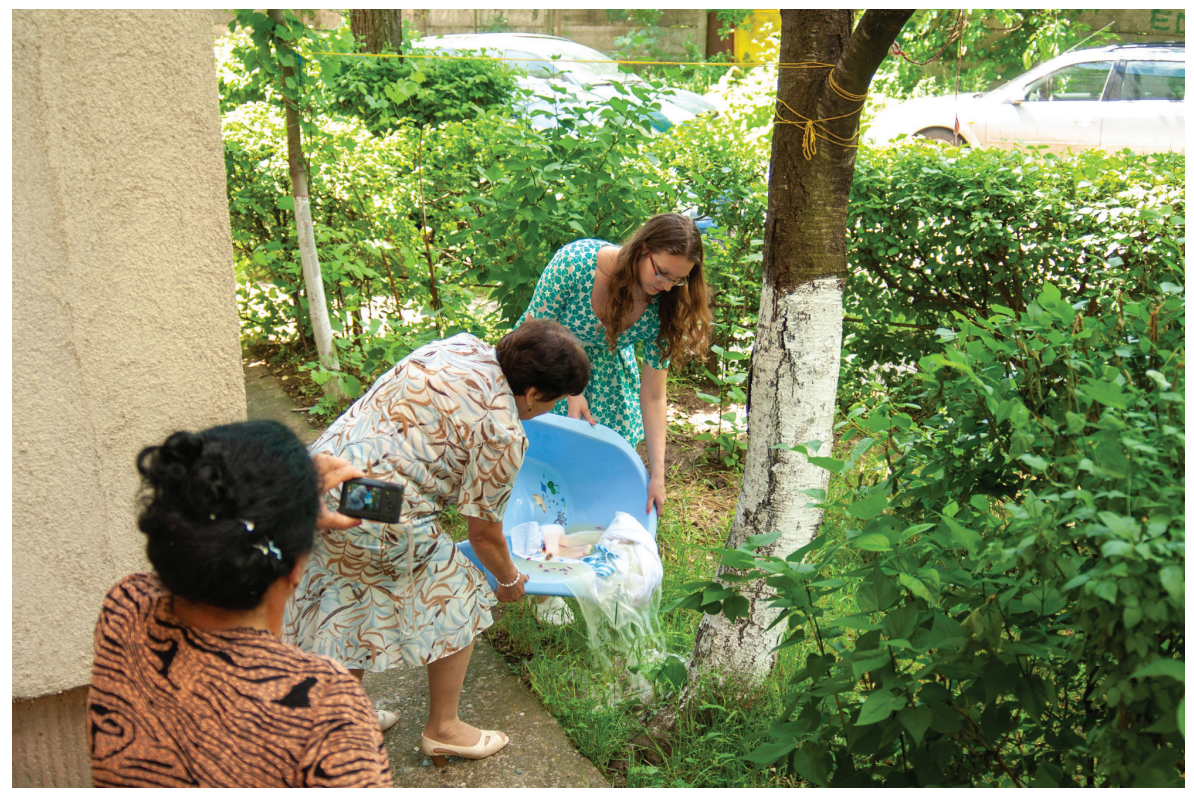

Figure 2. The ritual bathing water is poured at a tree in Iași. Photograph by Sergiu Ciubotariu 2013.

Figure 3. An olive tree planted near Rome, especially for the rite.

Photograph by Adina Hulubaș 2018.

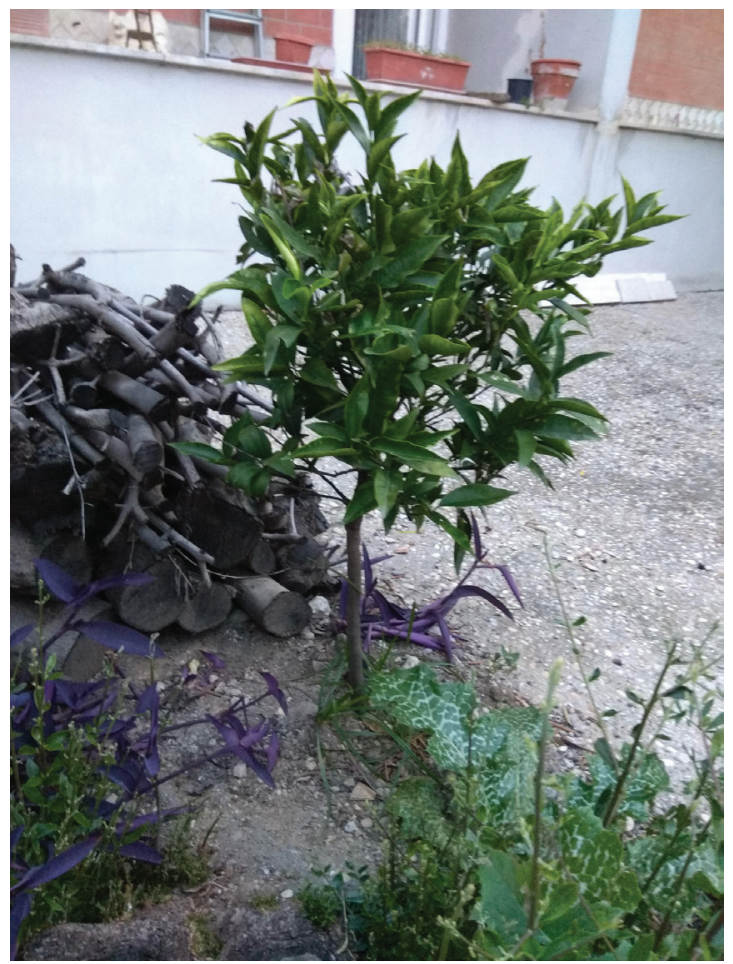


During the first bath and the one after baptism there were similar objects underneath the tub. The practice was maintained by L.N., who was living in Rome during the time of her child's scăldătoare (the washing performed by the godmother a day after christening). She placed a notebook, a pen, a comb, and a mirror under the bathtub, for her son to become smart, educated, and also handsome.

Holy water and drops of melted wax from the baptismal candle are further added in the bath. Hence, the water cannot be disposed of just as any other washing liquid. It has to be taken out and poured out at a tree while chanting and crying out (Fig. 2). The woman playing the role of a midwife leads the women's group regardless of the fact that they are in an urban area or even abroad. G.D. was in Rome when she had her guests carry the water down four storeys. A tangerine tree or an orange tree were too exotic for E.G. and M.N., considering the fact that they do not grow in the home country, Romania. Even more so, in the case of R.Z., the house owner bought him an olive tree especially for this occasion, and had it planted since there were no trees in front of the property (Fig. 3).

Urbanites also perform this ritual. M.D. declared that "you cannot throw the water down the drain, it is mandatory to pour it on a tall fruit tree, for the baby to grow tall and to bear fruit, to have offspring". E.B. believed that the child would be "beautiful like the tree", and G.M. added the feature of stateliness to the pleasant appearance. The practice was performed at childbirth, for the first bathing. The water used was taken to a tree, both by Romanians (Hulubaş 2012: 203) and Bulgarians: “the water from a baby's first bath was often emptied under a fruit tree, so that the child would 'grow as the tree grows"' (MacDermott 1998: 80).

A connection is thus established between the two, and the tree becomes an alter ego for the human being. However, the tree symbolism is ubiquitous during Romanian rites of passage, and the baby learns how to walk with the following words "Tree, little tree / Hold yourself like a tree" (in Tătăruşi village, Iaşi district). When the child grows up and gets married, a tree is decorated for the occasion. An alms tree is offered 40 days after death, since the deceased needs it in "the other world". Early in the morning of the first day of the New Year, children sing a ritual song called "Sorcova" and wish everybody to "grow old as an apple tree, as a pear tree". The verticality maintained even in heavy storms has transformed these tall plants into human ideals. All these beliefs are frequent among the Slavic people.

Among Luzatians in Polesie and in other Slavs' traditions, the custom to plant a fruit tree to mark the birth of a child is known, so that the child 
grows and develops like a tree. It was customary for all Slavs to pour the water in which they bathed the newborn under the fruit tree. Subsequently, the tree received the name of the child, and the Luzatians believed that it would grow like a tree, and the tree, in turn, would bring a rich harvest of fruit. In the case of a child's illness, they used this fruit tree for divinations about the child's fate: if the branches began to dry, they could die, and vice versa. Among the southern Slavs, it is a custom to bring the first cropped hair or nails of a child to a fruit tree, "so that the child develops like a fruit tree”. Among Bulgarians, fruit trees had a special role in the rituals of Babin Day, which is the traditional midwives' festival, many of whose magical acts were performed under the fruit tree. (Agapkina 1999: 71)

The energetic exchange between people and trees takes place in other circumstances as well. On the 1st of March people start wearing spring amulets called Mărţişoare and after 7 to 40 days they take them off and tie them to a blooming tree. Its condition during the year is an indicator of the well-being of the person who knotted the Mărţişor.

Contagious magic and analogies implied by these post-liminal rites confirm that "cultural acculturation comes after the material one, along with the process of integration to the urban setting" (Abraham 1991: 240). Therefore, traditional clothing, animal raising in the household and self-produced food are the first to disappear after migrating from the rural environment to internal urban settlements (international migration differs on the matter of traditional clothing, an increasing interest on ie - a hand-sewn shirt - being noticed in the past years), whereas rites and superstitions are performed continuously, for they also play a psychological role in the effort to cope with the new type of community. The future is not left to hazard and the family seems to be in control of outcomes. However, glimpses of the child's fate will be available just once more when they turn one and all their connections with the mysterious world they came from will be severed.

\section{THE FIRST TRIMMING AND FORETELLING OF THE CHILD'S OCCUPATION}

Up to the age of one, children are believed to be part of an unfamiliar universe. When adults are asked by the young where babies come from, they hide the process by answering in a mythological key. In the village of Ruginoasa, Neamt district, people still said in 1988 that newborns "are brought from the woods or taken from beneath the sun". Since children are not able to speak before the age 
of one, they seem to maintain a connection with this unknown origin. Moreover, the hair they grow during their first year of life belongs to the numinous place that created them. "To cut the hair is to separate oneself from the previous world" (Gennep 1960 [1909]: 166), and for the baby to fully come into the social environment the trimming must be performed by the godmother.

After this symbolic sacrifice that I will return to later, another glance at the future occupation is taken by the family, as if a secret door closes and one last peek is allowed. When the baby turns one, their godparents arrive at their house for the celebration, and a tray with various objects is presented to them. What they choose and take into their hand is to reveal the future job.

In the rural settlements investigated starting at the end of the 1960s, this rite was not found. The future occupation was mainly indicated by voluntary and involuntary acts. In the first category there was magic contagion provoked by the traditional birth attendant: specific tools appropriate for the sex of the baby were placed in his/her little hand right after the expulsion. For example, the newly born boy received a hammer, an axe, nails, a book and pencils or a whistle in his palm, whereas girls had a crochet and thread, a spindle or a needle in their little fists (Hulubaş 2012: 198). In 2011, a respondent from the village Hilița (Iaşi district) said that it is during the ritual bath after birth that the baby's future occupation reveals itself. Whatever objects float next to the baby's head indicate it. Later in the first year, when he/she starts toddling through the house, the first object coming to his/her hand speaks about what the child will do in life (Sălătruc, Bacău district).

The practice of actual choosing of an object has a long history in Asia. Documented as early as during the Song Dynasty (960-1279), Zhuazhou, which can be translated as "first birthday grab/pick", is celebrated when the baby is one year old. "The assortment of articles used to vary between boys and girls" (Zhao 2016 [2011]: 27) when they were subjected to this rite. In a manner similar to the old rural practice in Romania, Chinese boys used to receive a book, ink, money, and scissors (meaning they will become scholars, wealthy or tailors) for their pick, while girls had to choose from thread, a scoop, and a spoon (embroidery was suggested by the first, the other two items referred to cooking).

In Japan the practice is called Erabitori, meaning "choose and take an item". The selection of the objects is similar and so is the moment in the child's life. Boys would get a writing brush, ink, and an abacus, whereas girls find a book and a ruler in front of them (Ah Kim 2019: 97). Interestingly enough, in Armenia, Agra Hadig was initially purposed to find out the sex of the next baby (Rousseau 2017); the child around six months (the ritual is performed whenever their teeth erupt) had to choose between a knife (meaning that they would have a brother), or a comb/mirror (a sister was the next). The latter two 
items are still used by Vietnamese people, who celebrate Thôi Nôi ("to cease/ quit the cradle") when the baby turns one (Youmans 1887: 629). Money, a pencil, and a book are offered for their choice, all these also being present on the tray Romanians bring to their babies for the first birthday.

One more nation - the Koreans - celebrates the first year of life with this practice intended to look into the occupational future. Dol Janchi is "one of the most widely practiced birth customs today" (Kao 2012: 145). A pencil, a book, a ruler, money, thread, a needle, and scissors are given as ritual objects that foretell the occupation. Today, parents may keep using some items while rejecting others (Kao 2012: 146), a dynamic phenomenon that can also be observed at Romanians. Urbanites analyse the change in a rational manner; for example, M.D. says:

The parents place on the tray everything that comes to their mind, but they have bad ideas of putting the things that the child likes, that he/ she plays with frequently, together with new ones. Usually they put a little ball there, a toy car, car keys, maybe a syringe too, without thinking about what the baby will grab first. Of course the baby takes what he/she has never seen before!

The same judgement was made by M.T., who has been living in Rome, Italy, for the last fourteen years: "Everybody has an idea of what has to be presented to the child!" (Fig. 4)

While working with documents from the Folklore Archive of Moldavia and Bucovina I noticed that villagers in the second half of the twentieth century did not practice this forecasting rite; it was in urban settlements in the $2010 \mathrm{~s}$ that all parents made their children choose an item. However, Petru Caraman noted in 1956 that Aromanians (an ethnic group speaking a dialect of the Romanian language, mostly found south of the Danube River) used to present the one-year-old baby with a plate (tipsie) containing tools they selected carefully. The scholar argues that the rite is not a simple divination, but an attempt to influence the future by their own hierarchy of occupations (Caraman 2018 [2005]: 372). Only jobs agreed by parents are therefore available for selection, and the child's development is not left to chance.

Immigrants mentioned car keys, money, and gold rings as objects that might imply the child will be well-off, some paper, books, and pencils as symbols for an intellectual life, a lipstick and a comb as items suggesting an interest in beauty, and a fork or a spoon to see if the child will grow up to be a cook. C.T. declared that Romanian stores in Rome also sell kits for this occasion: a tray already set with various objects that might be decoded as job indicators. The first item picked up by the child is relevant from this point of view. 


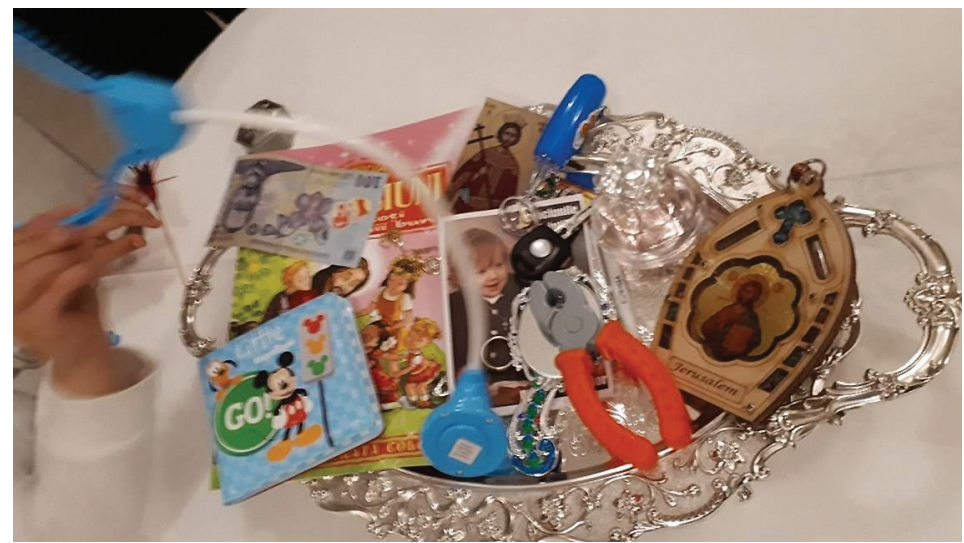

Figure 4. A tray with objects. Botoșani, Romania. Photograph by Alina Manolache 2019.

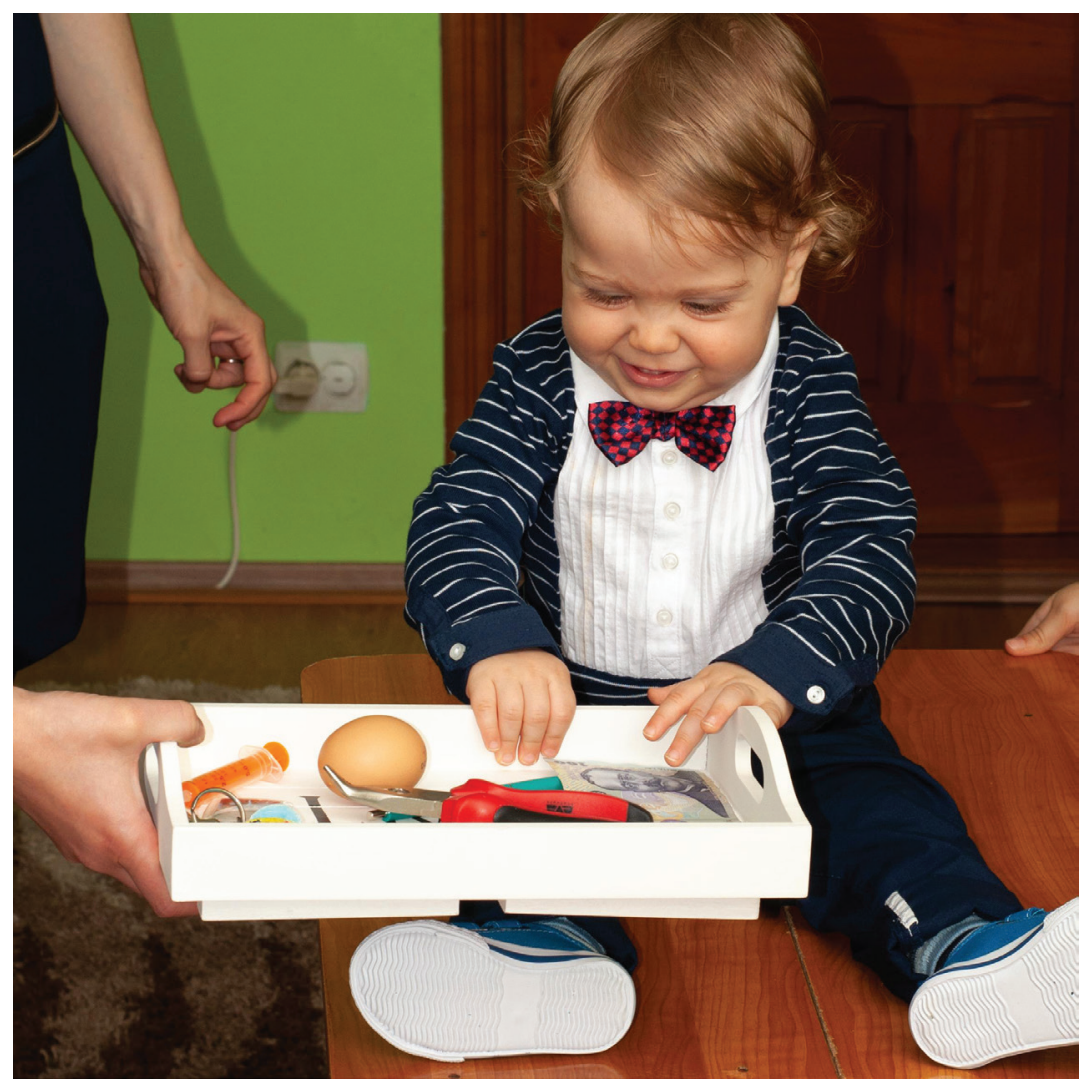

Figure 5. A boy is about to choose tongs from the tray. Iaşi, Romania. Photograph by Sergiu Ciubotariu 2014. 
Hence, many parents make the child choose three objects hoping that a better selection is thus obtained. Today smartphones, stethoscopes, or beads can be seen on the ceremonial tray, instead of hammers, tongs or scissors that were used in villages decades ago (Hulubaş 2014: 121). Among childbirth customs, this rite is most susceptible to modern influences, since it is directly linked to socio-economic development. There can no longer be a gender-based selection of items, but ideal occupations change in the collective mind. This rite of incorporation makes use of the last moments when the child stays in contact with the mysterious world they came from. This may explain their ability to recognize the tool that will define their life in the years to come (Fig. 5).

"The newborn comes from the invisible world, pertaining to the dead and to the night, in order to be integrated to the visible world, the one of the living and of the light" (Lepoutre 1997: 187). This image is familiar to the ritual songs that were sung at the baptism party (cumătrie) some time ago: "From a hole in the sedge / Here comes this Prince Charming / And he demands a hood and a necklace / To go to the white world" (Marian 1995: 158). The newborn enters the sparkling world of humans with the remanent energy. For this reason, the midwife and not anyone else has to carry them to church for christening; the godmother takes the baby in her arms only when the religious service starts. The hair that grew in the first year cannot be cut by anybody but her, since she is initiated and can handle numinous forces safely.

All the urbanites I talked to were familiar with the conviction that the godmother alone can cut the hair of the baby when he/she is one year old. C.T. lives in Rome and she told me she could hardly wait for the godparents to come and complete the ritual so that she could take the child to a hairdresser after that. In fact, the first time the child has his/her nails cut, it is the godmother who has to come and shorten them, otherwise the child will become a thief (Hulubaş 2012: 301). The same superstition was found among Italian immigrants from the United States of America (Malpezzi \& Clements 1998 [1992]: 65). For the first celebration, the godmother trims the baby's hair by cutting some tufts from four places on the head, suggesting the sign of a cross. She also cuts the nails and sticks the clippings on a coin with some melted wax from a candle. Sometimes it is the godfather who cuts the hair. In Gjakova, Kosovo, he performs this ritual on boys, while the godmother cuts the hair of girls (Kabakova 2000: 117).

This practice is also familiar to several other countries. Bulgaria and northern Ukraine are the closest countries to Romania where foretelling takes place in a similar manner (Sedakova 2009: 215). Here the baby lies on a sheepskin (kozhukh) and chooses from the items in front of him/her. This ritual element is significant during haircutting performed in the Lower Don region and on the western border with the Voronezh region in the Upper Don region: 
Of particular interest is the stable use of a kozhukh (a fur coat turned inside out), on which the child sat during haircutting, so that he/she would be rich. They laid out threads with needles, scissors, carpentry tools around the baby, or a book or cigarettes, bottles of alcohol, etc. From what the child reached out for, they learned what his / her character, fate would be, what they would do. (Vlaskina 2009: 454)

The sheepskin is also used by Romanians when the child is brought home from the church, and on the second day, during the bathing that follows christening. In several districts in Moldavia, the godparents cover the child with this fur whether in the mother's arms or on a table (Hulubaş 2012: 246). The next day, the sheepskin is placed underneath the bathing tub, with the conviction that the child will prove lucky in raising these animals, hence he/she will be rich (Hulubaș 2012: 255).

Lise Bartoli (2007: 236) mentions African and Asian people for whom "it would be bad luck to keep the first hair that is considered to be still impregnated by its previous supernatural universe". In the south of India caudaka is performed "in preparation for the "second birth"' of the child (Hüsken 2009: 68), that is, the social coming into the world. Mundana is the eighth of the sixteen Hindu sacraments called Samskāras - rites of passage (Pelissero 2014: 63) or sacraments. During this rite all the hair is removed from the baby's head to free them from their past lives and from less fortunate features they might have kept. The Chinese call this event "good luck trim", while religious communities shear the hair to express a spiritual integration of the new member (Upsherin for Orthodox and Hasidic Jews).

The practice of removing the newborn's hair has a long documented existence, and this underlines the vitality of the belief that covers both space (as we saw it in many cultures) and time (Fig. 6). No later than 200 A.D., Tertullian acknowledged the first haircut to be a custom inherited by Christianity (1854: 611). The transmission was uninterrupted; we find it in the same disapproving discourse in the seventeenth century, when Bartolomeo Bassetti advocated its ceasing (Holban 1980: 54). The trimming has remained the same across ages and cultures, all elements connecting the child with the past existence or the unknown world they came from being annulled successively. The dried umbilical cord, the nail clippings, and the locks are taken from the baby with the conviction that a new life needs a fresh, undefiled beginning.

Once cut, the hair can be either kept in the house or thrown in a specific place. It is a widely-spread belief in Romanian villages that the tuft represents the child's good luck in life (Hulubaş 2012: 304), therefore it needs to stay inside the household, not to lose the well-being of the entire family. Rural respondents declared that they kept it at a house beam, on the Orthodox icon that is hung on the highest point of the eastern wall, beneath the mirror, or in a chest. In Slavic 
beliefs, it has to be "hidden in the house, as high as possible, to stimulate the growing of the child" (Kabakova 2000: 117).

C.T., who has been living in Rome, Italy, for the last sixteen years, also took care of the hair fixed on a coin and placed it in a pouch in a memory book "to be safe there". The unconscious cultural heritage demanded her not to just throw it away. Like her, most of the urbanites did not feel the need to explain themselves as to why they were keeping the lock in their homes. G.M. remembered that in his native village people used to put it in cow manure "for the child to grow as well as cattle do", a gesture that is also found in Ukraine (Sedakova 2009: 214). E.I. said that the hair should be disposed of in a herd in order to bring good luck (in raising them in the future). Contagious magic is used once more to attract positive events, to make them a part of the child's destiny. Nothing is left to hazard; the life course is charted when entering the community is at its beginning.

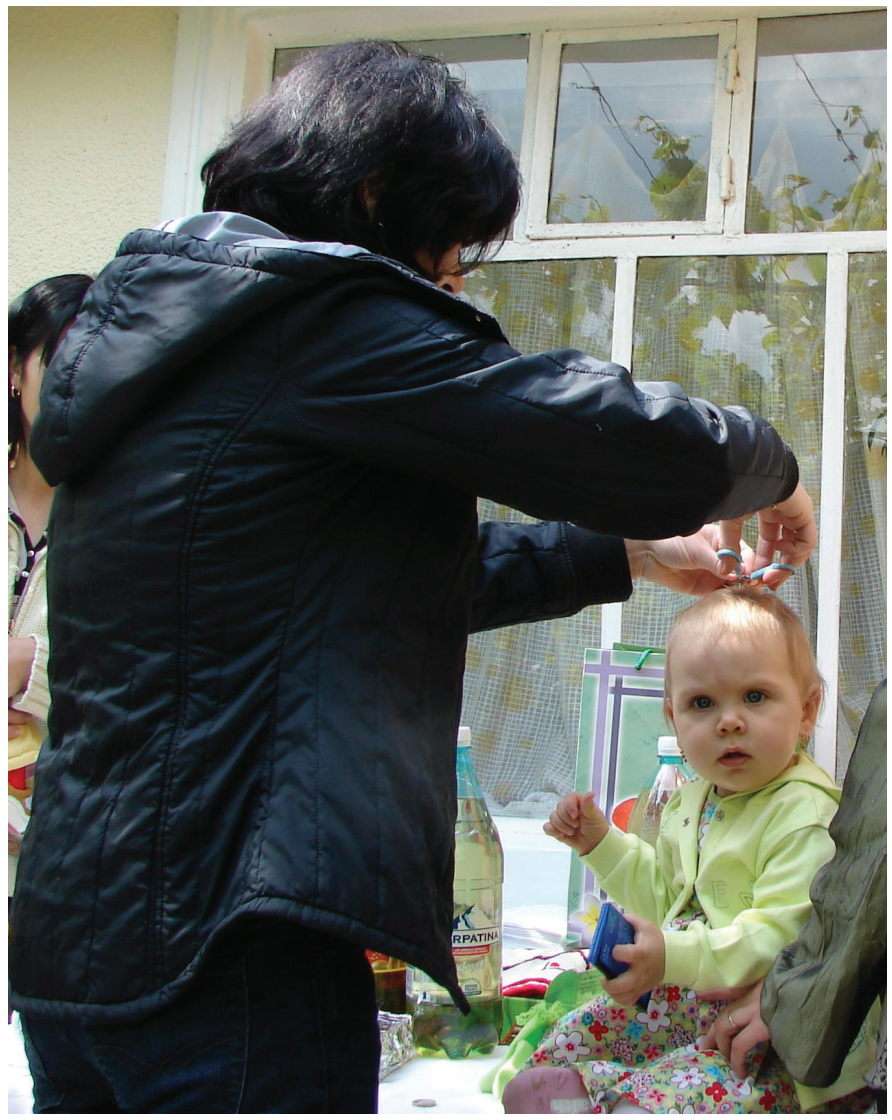

Figure 6. The godmother performs the symbolic first haircut in Tecuci, Romania. Photograph by Sergiu Chiubotariu 2008. 
Sometimes the hair becomes an offering to the surrounding nature. A tree reappears in the context of childbirth customs through the practice of putting the lock in it, so that the child's hair would grow as much as the tree (Hulubaş 2012: 304-305). In Motoșeni, in the district of Botoșani, Romania, people used to throw the first tuft cut from the head into a river, a practice that is also performed in eastern Slovakia and western Ukraine (Sedakova 2009: 214), and is similar to a Hindu ritual. Rishikesh is situated in the north of India and in this community boys are going through the Mundana ritual on the banks of the Ganges River (Agoramoorthy \& Hsu 2015: 1454). Their hair is washed away by the holy waters. People from central Thailand also worship rivers in this manner:

When the top-knot of a Siamese child has been cut with great ceremony, the short hairs are put into a little vessel made of plantain leaves and set adrift on the nearest river or canal. As they float away, all that was wrong or harmful in the child's disposition is believed to depart with them. (Frazer 1925 [1890]: 235)

The first haircut marks the end of taboos for the parent. The offspring now fully belongs to the social world and all wishful rituals are complete. The family is assured that the child's life will follow the path whose landmarks were set by rites. Displacement reinforces the inherited cultural behaviour, as we were able to see both for internal and international migration.

\section{CONCLUSIONS}

The article selected specific practices that on the one hand influence the becoming of the child, and on the other foretell their future. Rituals and superstitions that ward off the evil eye and other young-age afflictions are also well represented in Romanian childbirth practices, but they deal less with the future and more with the crucial moments of the early days, hence they are not discussed here. The fact that pregnant and parturient women as well as unbaptized children are highly receptive to the energies around them led to the appearance of two types of cultural reactions: apotropaic responses to the present possibly negative environment and gestures that augur well for the life to come. The latter intend to bring the generically called good luck (Rom. noroc) and I have analysed them in various ritual contexts.

Both preliminary and postliminary rites have an acknowledged psychological effect on mothers and their families. The attention on things that mould or tell the future also manages to ease the worries on the fate of the newborn. The pregnancy phase is tensed due to mothers being highly aware of the power of 
looking and being overlooked. Such superstitions have survived well in urban settlements and women try to take benefits from pleasant sightings. After birth the child is protected from the evil eye by a strategy that consists in a chromatic distraction.

Postliminary rites discussed above are centred on the figures of the godparents who have to be socially respectable. They will mould the future of the newborn in successive ways: by christening, during the second-day bath, by cutting their nails and hair, and by making the selection of objects to be chosen during the foretelling of the child's occupation. Obvious similarities with countries neighbouring Romania are joined by strikingly resembling practices and convictions from Tanzania, Armenia, China, India, Korea, Vietnam, Thailand, and Japan. Hence, the image of childbirth perception in the world is more complete, revealing common preoccupations and even social processes in coping with a new member of the family.

Examples from fairy tales and Christmas carols stress the magic imagery that I found in the active birth practices in Romania and abroad. Internal and international migration does not reduce the performing of traditional rites for the first generation; on the contrary, they enhance the need to participate in such identity-marked moments. Childbirth practices bear the most divinatory acts amongst the rites of passage and their continuation to the present day is remarkable. Despite the slight shift to aesthetic, entertaining purposes, each phase of these practices is performed in full conviction that the story of the new child will unfold as forecasted.

\section{ACKNOWLEDGEMENTS}

This work was supported by a grant of the Romanian Ministry of Research and Innovation, CCCDI - UEFISCDI, project number PN-III-P1-1.2PCCDI-2017-0116, within PNCDI III. Special thanks to Nina Vlaskina, who translated several Russian references and kindly made them available to me.

\section{NOTE}

1 The interviews were carried out within the series of projects "MIRO: Migration and identity in the Romanian cultural milieu. Research design, methodology, and expectations", supported by a grant of the Romanian Ministry of Research and Innovation, CCCDI - UEFISCDI, project number PN-III-Pl-1.2-PCCDI-2017-0116 I 48PCCDI/2018", within PNCDI III. 


\section{REFERENCES}

Abraham, Dorel 1991. Introducere în sociologia urbană. [Introduction to Urban Sociology.] Bucharest: Editura Ştiinţifică.

Agapkina, Tatiana 1999. Derevo plodovoe. [Fruit Tree.] In: Nikita Tolstoi (ed.) Slavianskie dreunosti:etnolingvisticheskii slovar'. Vol. 2. Moscow: Mezhdunarodnye otnosheniia, pp. 70-73. Available at https://vk.com/wall-112143772_8486, last accessed on 5 October 2020.

Agoramoorthy, Govindasamy \& Hsu, Minna J. 2015. Living on the Societal Edge: India's Transgender Realities. Journal of Religion and Health, Vol. 54, No. 4, pp. 14511459. http://dx.doi.org/10.1007/s10943-014-9987-z.

Ah Kim, Jeong 2019. A Study of Traditional Baby Rituals and Costumes of Japan. Journal of the Korean Society of Costume, Vol. 69, No. 7, pp. 91-108. https://doi.org/10.7233/ jksc.2019.69.7.091.

Bartoli, Lise 2007. Venir au monde. Les rites de l'enfantement sur les cinq continents. Paris: Édition Payot \& Rivages.

Brătulescu, Monica (ed.) 1964. La luncile soarelui. Antologie a colindelor laice. [On the Fields of the Sun. Laic Carols Anthology.] Bucharest: Editura Pentru Literatură.

Callister, Lynn Clark 1998. Giving Birth: Guatemalan Women's Voices. Journal of Obstetric, Gynecologic, and Neonatal Nursing, Vol. 27, No. 3, pp. 289-295. https:// doi.org/10.1111/j.1552-6909.1998.tb02651.x.

Caraman, Petru 2018 [2005]. Restituiri etnologice. [Ethnological Restitutions.] Edited, introduction and notes by Ion H. Ciubotaru. Iaşi: Editura Universităţii “Alexandru Ioan Cuza".

Ciubotaru, Ion H. 2012. Ouăle de Paşti la români. Vechime, semnificaţii, implicații ritual-ceremonial. [Easter Eggs at Romanians. Age, Meanings, Ritual-ceremonial Implications.] Iaşi: Editura Presa Bună.

Creţu, Vasile Tudor 2014. Ethosul folcloric - sistem deschis. Existenţa ca întemeiere. [The Folkloric Ethos - an Open System. Existence as a Foundation.] Timişoara: Editura Universităţii de Vest.

Frazer, James George 1925 [1890]. The Golden Bough: A Study in Magic and Religion. Abridged edition. New York: The Macmillan Company. Available at https://archive. org/details/cu31924021569128, last accessed on 5 October 2020.

Geertz, Clifford 1957. Ritual and Social Change: A Javanese Example. American Anthropologist, Vol. 59, No. 1, pp. 32-54. https://doi.org/10.1525/aa.1957.59.1.02a00040.

Gélis, Jacques 1991. History of Childbirth: Fertility, Pregnancy, and Birth in Early Modern Europe. Boston: Northeastern University Press.

Gennep, Arnold van 1960 [1909]. The Rites of Passage. Transl. by Monika B. Vizedom \& Gabrielle L. Caffee. Introduction by Solon T. Kimball. Chicago: University of Chicago Press.

Golovakha-Hicks, Inna 2008. The Life of Traditional Demonological Legends in Contemporary Urban Ukrainian Communities. Folklore: Electronic Journal of Folklore, Vol. 40, pp. 37-44. http://dx.doi.org/10.7592/FEJF2008.40.golovakha.

Holban, Maria (ed.) 1980. Călători străini despre Ţările Române. [Foreign Travellers about Romanian Lands.] Vol. VII. Bucharest: Editura Ştiinţifică şi Enciclopedică. Available at https://ru.calameo.com/read/0008274337a09cc1eb04b, last accessed on 5 October 2020. 
Hulubaş, Adina 2012. Obiceiuri de naştere din Moldova. Tipologie şi corpus de texte. [Childbirth Customs from Moldavia. A Typology and Texts Corpus.] Iaşi: Editura Universităţii "Alexandru Ioan Cuza". Available at https://www.academia. edu/9703923/Obiceiuri_de_nastere_din_Moldova._Tipologie_si_corpus_de_texte, last accessed on 5 October 2020.

Hulubaş, Adina 2014. Credinţe despre naştere în contextual urban din Moldova: Memoria tradiţională. [Childbirth Beliefs in the Urban Context in Moldavia: The Traditional Memory.] Iaşi: Editura Universităţii “Alexandru Ioan Cuza”. Available at https:// www.academia.edu/9703941/Credinte_despre_nastere_in_contextul_urban_din Moldova._Memoria_traditionala, last accessed on 5 October 2020.

Hüsken, Ute 2009. Vișinu's Children. Prenatal Life-cycle Rituals in South India. Wiesbaden: Harrassowitz Verlag.

Jordan, Brigitte \& Davis-Floyd, Robbie 1993 [1978]. Birth in Four Cultures: A Crosscultural Investigation of Childbirth in Yucatan, Holland, Sweden, and the United States. 4th ed. Prospect Heights: Waveland Press.

Kabakova, Galina 2000. Anthropologie du Corps Féminin dans le Monde Slave. Paris: L'Harmattan.

Kao, Grace Y. 2012. Exploring the Korean First Birthday Celebration (Dol Janchi) as a Site for Comparative Religious Ethics and Asian American Christian Ethics. In: Elizabeth M. Bucar \& Aaron Stalnaker (eds.) Religious Ethics in a Time of Globalism. New York: Palgrave Macmillan, pp. 145-176. https://doi. org/10.1057/9781137273031_7.

Laderman, Carol 1984. Food Ideology and Eating Behavior: Contributions from Malay Studies. Social Science \& Medicine, Vol. 19, No. 5, pp. 547-559. https://doi. org/10.1016/0277-9536(84)90050-9.

Lepoutre, Marie 1997. D’une médecine à l'autre. Grossesse et enfantement: ethno-histoire du pluralisme medical à Lifou Nouvelle-Caledonie, Thése de Doctorat. EHESS.

Liamputtong, Pranee 2009. Pregnancy, Childbirth and Traditional Beliefs and Practices in Chiang Mai, Northern Thailand. In: Helaine Selin (ed.) Science across Cultures: The History of Non-Western Science. Vol. 5. Childbirth Across Cultures, Science Across Cultures: Ideas and Practices of Pregnancy, Childbirth and the Postpartum. Dordrecht: Springer, pp. 175-184. https://doi.org/10.1007/978-90-481-2599-9_15.

Mabilia, Mara 2007 [2005]. Breast Feeding and Sexuality. Behaviour, Beliefs and Taboos among the Gogo Mothers in Tanzania. Transl. by Mary S. Ash. New York \& Oxford: Berghahn Books.

MacDermott, Mercia 1998. Bulgarian Folk Customs. London \& Philadelphia: Jessica Kingsley Publishers Ltd.

Malpezzi, Frances M. \& Clements, William M. 1998 [1992]. Italian-American Folklore. Little Rock: August House Inc.

Marian, Simeon Florea 1995. Naşterea la români: Studiu etnografic. [Childbirth at Romanians: An Ethnographic Study.] Bucharest: Editura Grai şi Suflet - Cultura Naţională.

Mathole, Thubelihle \& Shamu, Simukai 2009. Childbirth in Zimbabwe. In: Helaine Selin (ed.) Science across Cultures: The History of Non-Western Science, Vol. 5. Childbirth Across Cultures, Science Across Cultures: Ideas and Practices of Pregnancy, Childbirth and the Postpartum. Dordrecht: Springer, pp. 205-213. https://doi. org/10.1007/978-90-481-2599-9_18. 
Mongeau, Beatrice \& Smith, Harvey L. \& Maney, Ann C. 1961. The "Granny" Midwife: Changing Roles and Functions of a Folk Practitioner. American Journal of Sociology, Vol. 66, No. 5, pp. 497-505. https://doi.org/10.1086/222972.

Pelissero, Alberto 2014. Introducere în Hinduism. [Introduction to Hinduism.] Iaşi: Editura Polirom.

Pop, Mihai \& Ruxăndoiu, Pavel 1978 [1976]. Folclor literar românesc. [Romanian Literary Folklore.] Bucharest: Editura Didactică şi Pedagogică.

Redfield, Robert 1947. The Folk Society. American Journal of Sociology, Vol. 52, No. 4, pp. 293-308. https://doi.org/10.1086/220015.

Rousseau, Bryant 2017. In Armenia, 'What Do You Want to Be?' Is Asked in Infancy. The New York Times, 12 March. Available at https://www.nytimes.com/2017/03/12/ world/europe/armenia-atam-hatik-agra-hadig.html, last accessed on 5 October 2020.

Sedakova, Irina 2009. Postrizhiny. [Haircutting.] In: Nikita Tolstoi (ed.) Slavianskie dreunosti: etnolingvisticheskii slovar'. Vol. 4. Moscow: Mezhdunarodnye otnosheniia, pp. 212-215.

Teodorescu, G. Dem (ed.) 1996. Basme române. [Romanian Fairy-tales.] Bucharest: Editura Vitruviu.

Tolstaia, Svetlana 2009. Pravyi - levyi. [Right - Left.] In: Nikita Tolstoi (ed.) Slavianskie drevnosti: etnolinguisticheskii slovar'. Vol. 4. Moscow: Mezhdunarodnye otnosheniia, pp. 233-237.

Tertullian, Quinti Septimii Florentis 1854. Quae Supersunt Omnia. Vol. II. Edited by Franciscus Oehler. Leipzig: T. O. Weigel.

Văduva, Ofelia 1997. Magia darului. [The Magic of the Gift.] Bucharest: Editura Enciclopedică. Vlaskina, Tatiana 2009. Pervaia godovshchina rozhdeniia rebenka v traditsiiakh donskikh kazakov. [First Anniversary of a Child's Birth in Don Cossacks'Traditions.] Problemy istorii, filologii, kultury / Journal of Historical, Philological and Cultural Studies, Vol. 23, No. 1, pp. 446-456. Available at https://cyberleninka.ru/article/n/pervayagodovschina-rozhdeniya-rebenka-v-traditsiyah-donskih-kazakov, last accessed on 5 October 2020.

Werner, Heinz 1980 [1926]. Comparative Psychology of Mental Development. New York: International Universities Press.

Youmans, William J. (ed.) 1887. Ethnological Sketches in Annam and Tonquin. The Popular Science Monthly, Vol. 31, pp. 626-635. Available at https://en.wikisource.org/wiki/ Popular_Science_Monthly/Volume_31/September_1887/Ethnological_Sketches_in_ Annam_and_Tonquin, last accessed on 5 October 2020.

Zhao, Lucy 2016 [2011]. Rituals and the Life Cycle. In: Xiaowei Zang (ed.) Understanding Chinese Society. 2nd ed. London \& New York: Routledge, pp. 25-35. Available at https://sgp1.digitaloceanspaces.com/proletarian-library/My-library/Xiaowei\%20 Zang/Understanding\%20Chinese\%20Society\%20(434)/Understanding\%20 Chinese\%20Society\%20-\%20Xiaowei\%20Zang.pdf, last accessed on 5 October 2020.

Adina Hulubaş is Senior Research Fellow working at the Iaşi Branch of the Romanian Academy. She took her doctoral degree on initiatory rites in Romanian literary folklore in 2009. Her main research areas are childbirth customs, vernacular architecture, traditional occupations, folklore didactics, and intangible cultural heritage. She has been a member of UNESCO Global Network of Facilitators since 2017.

adina.hulubas@gmail.com 